\title{
Hubungan Kedisiplinan Belajar dan Motivasi Belajar dengan Cara Belajar Peserta Didik
}

\author{
Yoga Pratama Putra ${ }^{1}$, M.Th.S.R.Retnaningdyastuti ${ }^{2}$, Agus Setiawan ${ }^{3}$ \\ Bimbingan dan Konseling Fakultas Ilmu Pendidikan \\ Universitas PGRI Semarang \\ e-mail : yp2549087@gmail.com ${ }^{1}$, retna834@gmail.com ${ }^{2}$, agussetiawan@upgris.ac.id ${ }^{3}$
}

\begin{abstract}
Abstrak
Penelitian ini bertujuan untuk mengetahui hubungan kedisiplinan belajar dan motivasi belajar dengan cara belajar. Penelitian ini merupakan penelitian ex-post facto untuk menggambarkan hubungan variabel independen (kedisiplinan belajar dan motivasi belajar dengan cara belajar) terhadap variabel dependen (cara belajar). Jenis penelitian ini adalah kuantitatif dengan metode ex post facto. Populasi dalam penelitian ini siswa kelas VIII SMP N 1 Kandangserang Pekalongan dengan jumlah 120 siswa. Kelas VIII A-D masing-masing diambil 5 orang dipergunakan untuk try out. Sampel dalam penelitian ini adalah 88 siswa kelas VIII SMP $\mathrm{N} 1$ Kandangserang Pekalongan yang diambil dengan teknik proportional random sampling. Alat pengumpulan data yang dipergunakan adalah skala kedisiplinan belajar, dan motivasi belajar dengan cara belajar. Sampel penelitian ini adalah siswa kelas VIII SMP N 1 Kandagserang Pekalongan, sampel penelitian ini dipilih secara acak (Propotionate Random Sampling). Jenis data penelitian ini adalah data interval yang diperoleh dengan penyebaran skala likert. Hasil uji yang telah dilakukan mempunyai hasil sebesar 0,000. Hal ini menunjukkan bahwa nilai Sig. $<\alpha^{\text {Sig. }}<\alpha$ atau $0,000<0,05^{0,000}<0,05$, sehingga dapat ditarik kesimpulan terdapat hubungan yang signifikan antara kedisiplinan belajar dan motivasi belajar dengan cara belajar siswa kelas VIII SMP N 1 Kandangserang Pekalongan.
\end{abstract}

Kata-kata kunci: kedisiplinan, motivasi belajar, cara belajar

\begin{abstract}
Research into the relationship of learning discipline and learning motivation by means of student learning in class VIII SMP N 1 Kandangserang Pekalongan was motivated by students who experienced problems of low learning discipline and learning motivation by student learning. This type of research is quantitative with the ex post facto method. The population in this study was grade VIII students of SMP N 1 Kandangserang Pekalongan with a total of 120 students. Class VIII A-D each taken 5 people each used to try out. The sample in this study was 88 students of class VIII SMP N 1 Kandangserang Pekalongan taken by proportional random sampling technique. Data collection tools used are the scale of learning discipline, and motivation to learn by learning.Based on the results of the study concluded the following conclusions: (1) There is a positive and significant relationship between learning discipline and ways of learning. It is proven that tcount> ttable or 4,572> 0,665 Sig. generated at 0,000. This is proven by the value of Sig.or 0,000 $<0.05$ (2) There is a positive relationship between learning motivation and learning methods. This is evidenced by the tcount for the learning motivation variable of 6.306 and a table of 1.987. This shows that tcount> ttable or 6.306>0.665 with Sig. generated at 0,000. This shows that the value of Sig. $<A$ or $0,000<0.05$. (3) There is a positive relationship between learning discipline and learning motivation with the learning methods of students of class VIII SMP N 1 Kandangserang Pekalongan. Based on this research shows that there is a relationship between learning discipline and learning motivation with learning. This is evidenced by the significant value that $F$ count $>F$ table or 21.152> 3.09 with Sig. generated at 0,000 . This shows that the value of Sig. $<A$ or $0,000<0.05$. The coefficient of determination $R 2$ that is generated by 0.320 results shows that learning discipline (XI) and motivation to learn (X2) jointly influence the way of learning $(Y)$ as much as the rest are influenced by other variables that are outside the data testing model.It is recommended that BK teachers should provide counseling guidance services according to student needs. Students who have problems in the high category should be given individual counseling or group counseling. In accordance with student needs.
\end{abstract}

Keywords: learning discipline, learning motivation, how to learn 


\section{Pendahuluan}

Pembelajaran merupakan suatu proses interaksi yang saling berhubungan satu sama lain dan saling ketergantungan antara peserta didik, guru dan sumber belajar dalam lingkungan belajar. $\mathrm{Di}$ dalam pembelajaran terjadi proses memperoleh ilmu dan pengetahuan, penguasaan, kemampuan serta membentuk sikap serta kepercayaan pada peserta didik yang hasilnya dapat dilihat melalui prestasi belajar. Prestasi belajar tidak hanya berfungsi untuk mengetahui tercapai atau tidaknya tujuan pembelajaran, namun juga sebagai tolak ukur sekolah dan guru untuk mengetahui perubahan tingkah laku pada siswa. Dalam proses pembelajaran dikatakan efektif apabila terjadi perubahan tingkah laku pada siswa setelah mengikuti proses belajar. Oleh karena itu, prestasi belajar dan proses belajar merupakan dua unsur yang saling berkaitan satu sama lain karena capaian prestasi belajar siswa merupakan akibat dari proses pembelajaran yang ditempuh siswa selama proses pembelajaran. Bagi orang tua, prestasi belajar berfungsi untuk melihat sejauh mana kemampuan anaknya dalam menguasai berbagai bidang studi "Cara belajar merupakan sebuah pendekatan yang menjelaskan bagaimana individu belajar atau jalan yang ditempuh oleh masing-masing individu untuk berkonsentrasi pada proses belajar, menguasai informasi yang sulit dan baru melalui presepsi yang berbeda". Pengertian cara belajar yang lain menyebutkan "Cara belajar peserta didik adalah perilaku konsisten yang dilakukan oleh seorang murid dalam menangkap stimulus atau informasi, cara mengingat, berfikir dan memecahkan masalah". Menurut Ghufron (dalam Hera 2016:103)

Kedisiplinan belajar mempunyai kaitan dengan cara belajar, terlihat dari masih di temukan permasalahan yang mengakibatkan hasil belajar kurang optimal, yaitu rendahnya disiplin belajar. Hamzan (2016:7)

Motivasi belajar juga sangat berpengaruh terhadap cara belajar siswa. Motivasi untuk belajar adalah kondisi psikologis yang mendorong seseorang untuk mau belajar. Motivasi belajar merupakan salah satu karakteristik yang dapat mempengaruhi aspek afektif. Motivasi dapat berupa keinginan untuk menjadi juara kelas, keinginan untuk mendapat beasiswa, keinginan untuk membahagiakan orang tua dan lain sebagainya. Jika semua keinginan itu sangat kuat, otomatis akan membangkitkan tenaga yang luar biasa dalam diri untuk dapat mencapai keinginan terse but. Siswa yang memiliki motivasi belajar akan memperhatikan dan berusaha untuk mengingat apa yang telah diajarkan oleh guru, karena semua itu untuk mencapai cita-citanya

Menurut Gunarsa (2017:2) disiplin belajar merupakan ketaatan dan kepatuhan terhadap peraturan tertulis maupun yang tidak tertulis dalam proses perubahan tingkah laku yang menetap akibat dari praktik yang berupa pengalaman mengamati, membaca, menirukan, mencoba sesuatu, mendengarkan, serta mengikuti arahan.

Tetapi faktanya di lapangan pada tanggal 23 Juli 2019berdasarkan hasil dari AKPD di kelas VIII SMP Negeri 1 Kandangserang Pekalaongan menujukan prosentase yang merasa sulit mematuhi tata tertib di sekolahan (12,37\%). Permasalahn di atas diperkuat dengan hasil wawancara guru BK SMP N 1 Kandangserang Pekalongan berdasarkan pada hasil wawancara terbuka dengan koordinator guru bimbingan dan konseling yang dilakukan pada tanggal 23 Juli 2019 di SMP N 1 Kandangserang Pekalongan secara langsung bahwa kondisi peserta didik kelas VIII terungkap bahwa permasalahan yang sedang dihadapi saat ini, yaitu terkait dengan banyaknya peserta didik yang peserta didik yang kedisiplinan belajarnya itu sangat kurang.

Permasalahan di atas juga didukung oleh hasil observasi tanggal 24 Juli 2019 bahwa peserta didik kelas VIII juga terdapat belum disiplin saat berangkat sekolah banyak yang terlambat dan juga pelajaran akan berlangsung juga masih yang belum mempersiapkan pelajaran yang akan di pelajari.

Berdasarkan hasil dari AKPD, wawancara dan observasi dengan guru BK di atas menunjukkan bahwa masih banyak peserta didik mengalami masalah kedisiplinan belajar.

Maka penelitian ini bertujuan Mengetahui hubungan kedisiplinan belajar dengan cara belajar. Mengetahui motivasi belajar dengan cara belajar. Mengetahui hubungan kedisiplinan belajar dan motivasi belajar, dengan cara belajar. 


\section{Metode}

Metode penelitian ini adalah metode korelasi dengan menggunakan analisis regresi yang bertujuan untuk mengetahui ada tidaknya hubungan antara cara belajar, kedisiplinan belajar, dan motivasi belajar siswa kelas VIII SMP N 1 Kandangserang Pekalongan berdasarkan angka koefisien korelasinya. Penelitian ini termasuk penelitian ex-post facto di mana data yang dihasilkan berupa angka yang termasuk dalam penelitian kuantitatif. Penelitian ex-post facto merupakan penelitian di mana varaibel-variabel bebas telah terjadi ketika peneliti mulai dengan variabel terikat dalam suatu penelitian (Sukardi, 2008: 165)

Sesuai dengan pernyataan di atas, maka pada penelitian ini hanya ingin mengetahui hubungan variabel bebas yaitu kedisiplinan belajar dan motivasi belajar terhadap variabel terikat yaitu cara belajar, sehingga data yang berupa skor dari variabel akan menjawab hipotesis penelitian. Pada penelitian ini variabel bebas $(\mathrm{X} 1),(\mathrm{X} 2)$ dan variabel terikat $(\mathrm{Y})$ sudah dinyatakan secara nyata, kemudian dihubungkan sebagai penelitian korelasi atau prediksi jika variabel bebas mempunyai hubungan tertentu pada variabel terikat.

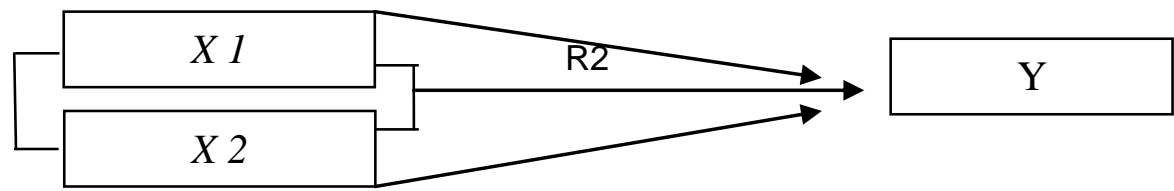

Gambar 01 Desain Penelitian

Keterangan :

$\mathrm{X} 1$ : Kedisiplinan belajar

$\mathrm{X} 2$ : Motivasi belajar

$\mathrm{Y}$ : Cara belajar

R2 : Regresi Ganda

Sugiyono (2016: 193) mengatakan teknik pengumpulan data dilakukan dengan cara wawancara, angket, dan observasi skala psikologi. Dalam penelitian ini peneliti menggunakan skala psikologis karena yang akan diungkap berupa atribut psikologis, Atribut psikologis secara tidak langsung diungkap melalui indikator-indikator skala cara belajar, kedisiplinan belajar dan motivasi belajar, kemudian menyusun pernyataan psikologis dengan format stimulusnya berbentuk pernyataan objektif dengan skoring menggunakan skala Likert empat alternatif jawaban yaitu: sangat sesuai, (SS), sesuai (S), tidak sesuai (TS), sangat tidak sesuai (STS). Adapun kriteria pemberian skor jawaban disajikan dalam bentuk berikut

Tabel 01 Distribusi Pemberian Skor

\begin{tabular}{ccccc}
\hline Pernyataan & \multicolumn{4}{c}{ Skor } \\
\cline { 2 - 5 } & $\begin{array}{c}\text { Sangat setuju } \\
\text { (SS) }\end{array}$ & Setuju (S) & $\begin{array}{c}\text { Tidak Setuju } \\
\text { (TS) }\end{array}$ & $\begin{array}{c}\text { Sangat Tidak } \\
\text { Setuju (STS) }\end{array}$ \\
\hline Favorabel & 4 & 3 & 2 & 1 \\
Unfavorabel & 1 & 2 & 3 & 4 \\
\hline
\end{tabular}

Menurut Sugiyono (2016: 118) sampel adalah bagian dari jumlah dan karakteristik yang dimiliki oleh populasi tersebut.Untuk itu sampel yang diambil dari populasi harus betul-betul representatif (mewakili). Untuk populasi 120 dengan taraf kesalahan 5\% maka jumlah sampelnya adalah 88 siswa(menggunakan table Isac dan Michael.

Tabel 02 Distribusi Sampel

\begin{tabular}{cccc}
\hline No. & Kelas & Populasi & Sampel \\
\hline 1. & VIII A & 30 & $\frac{88}{120} \times 30=22$ \\
2. & VIII B & 30 & $\frac{88}{120} \times 30=22$ \\
3. & VIII C & 30 & $\frac{88}{120} \times 30=22$
\end{tabular}




\begin{tabular}{ccc} 
4. VIII D & 30 & $\frac{88}{120} \times 30=22$ \\
\hline & Jumlah & 88
\end{tabular}

\section{Hasil dan Pembahasan}

Deskriptif data penelitian bertujuan untuk mengetahui gambaran masing- masing variabel XI, X2 dan Y, yang mana data tersebut di dapatkan dari SMP N 1 Kandangserang Pekalongan yang menjadi perwakilan untuk di teliti adalah siswa kelas VIII.

\section{Cara Belajar Siswa Kelas VIII SMP N 1 Kandangserang Pekalongan}

Variabel cara belajar memiliki nilai modus sebesar 73 , berarti bahwa nilai kelompok cara belajar yang dimiliki oleh 88 siswa berada pada angka 73. Untuk nilai median sebesar 68.00 , yang berarti nilai tengah dari 88 siswa terletak 68.00, sementara untuk nilai mean yang dimiliki oleh 88 siswa sebesar 68.77 termasuk kategori tinggi. Skala yang digunakan berisi tentang pernyataan mengenai cara belajar yang digunakan untuk mengetahui cara belajar siswa kelas VIII. Sebanyak 31 pernyataan yang diberikan dalam bentuk skala Likert, siswa dapat memilih pendapat yang paling sesuai dengan dirinya. Hasil analisis pengisian skala tersebut dikategorikan dalam empat tingkat yaitu sangat tinggi, tinggi, rendah, sangatrendah.

Tebel 03 Kategori Interval Cara Belajar

\begin{tabular}{cccc}
\hline Kelas Interval & Frekuensi & Presentase & Kategori \\
\hline $75-82$ & 17 & $18,2 \%$ & Sangat Tinggi \\
$67-74$ & 42 & $45,3 \%$ & Tinggi \\
$59-66$ & 22 & $24 \%$ & Rendah \\
$51-58$ & 7 & $7,5 \%$ & Sangat Rendah \\
Jumlah & 88 & $100 \%$ & \\
\hline
\end{tabular}

Diperoleh informasi bahwa 88 siswa yang menjadi responden dalam penelitian ini, subjek dengan kategori cara belajar sangat tinggi sebanyak 18,2\%, siswa dengan kategori tinggi sebanyak $45,3 \%$, siswa dengan kategori rendah sebanyak $24 \%$, siswa dengan kategori sangat trendah sebanyak $75 \%$. Dengan demikian dilihat dari reratanya maupun dari mayoritasnya, dapat dinyatakan bahwa tingkat cara belajar siswa di SMP N 1 Kandangserang Pekalongan ternasuk dalam kategoritinggi.

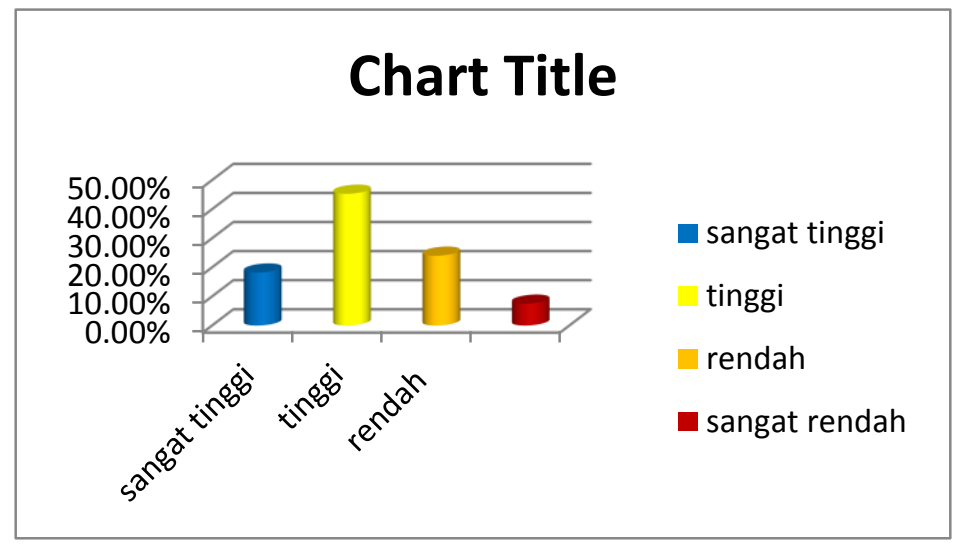

Gambar 02 Diagram cara belajar 
Dapat dilihat bahwa secera keselurahan cara belajar siswa sebagian besar masuk dalam kategori tinggi dengan hasil frekuensi 42. Kategori ini bisa diartikan sebagai kategori siswa memiliki cara belajar yang tinggi.

\section{Kedisiplinan belajar Siswa Kelas VIII SMP Negeri 1 Kandangserang Pekalongan}

Variabel kedisiplina belajar memiliki nilai modus sebesar 60 , berarti bahwa nilai kelompok kedisiplinan belajar yang dimiliki oleh 88 siswa berada pada angka 60 . Untuk nilai median sebesar 62.00 , yang berarti nilai tengah dari 88 siswa terletak 62.00 , sementara untuk nilai mean yang dimiliki oleh 88 siswa sebesar 62.33 termasuk kategori rendah. skala yang digunakan berisi tentang pernyataan mengenai kedisiplinan belajar yang digunakan untuk mengetahui kedisiplinan belajar siswa kelas VIII. Sebanyak 32 pernyataan yang diberikan dalam skala ini, siswa dapat memilih pendapat yang paling sesuai dengan keadaan dirinya dirinya. Hasil ananlisis pengisian skala tersebut dikategorikan dalam empat tingkat yaitu

Tabel 04 Kategori Interval Kedisiplinan Belajar

\begin{tabular}{cccc}
\hline Kelas Interval & Frekuensi & Persentase & Kategori \\
\hline $81-90$ & 1 & $1,0 \%$ & Sangat Tinggi \\
$71-80$ & 23 & $24,95 \%$ & Tinggi \\
$62-70$ & 50 & $51,9 \%$ & Rendah \\
$53-61$ & 14 & $15,05 \%$ & Sangat Rendah \\
\hline Jumlah & $\mathbf{8 8}$ & $\mathbf{1 0 0} \%$ & \\
\hline
\end{tabular}

Diperoleh hasil dari 88 siswa yang menjadi responden dalam penelitian ini, subjek dengan kategori kedisiplinan belajar sangat tinggi sebanyak 1,0\%, siswa dengan kategori tinggi sebanyak $24,95 \%$, siswa dengan kategori rendah sebanyak $51,9 \%$, siswa dengan kategori sangat rendah sebanyak $15,05 \%$. Dengan demikian dilihat dari reratanya maupun dari mayoritasnya, dapat dinyatakan bahwa tingkat kedisiplinan belajar siswa di SMP N 1 Kandangserang Pekalongan termasuk dalam kategori rendah.

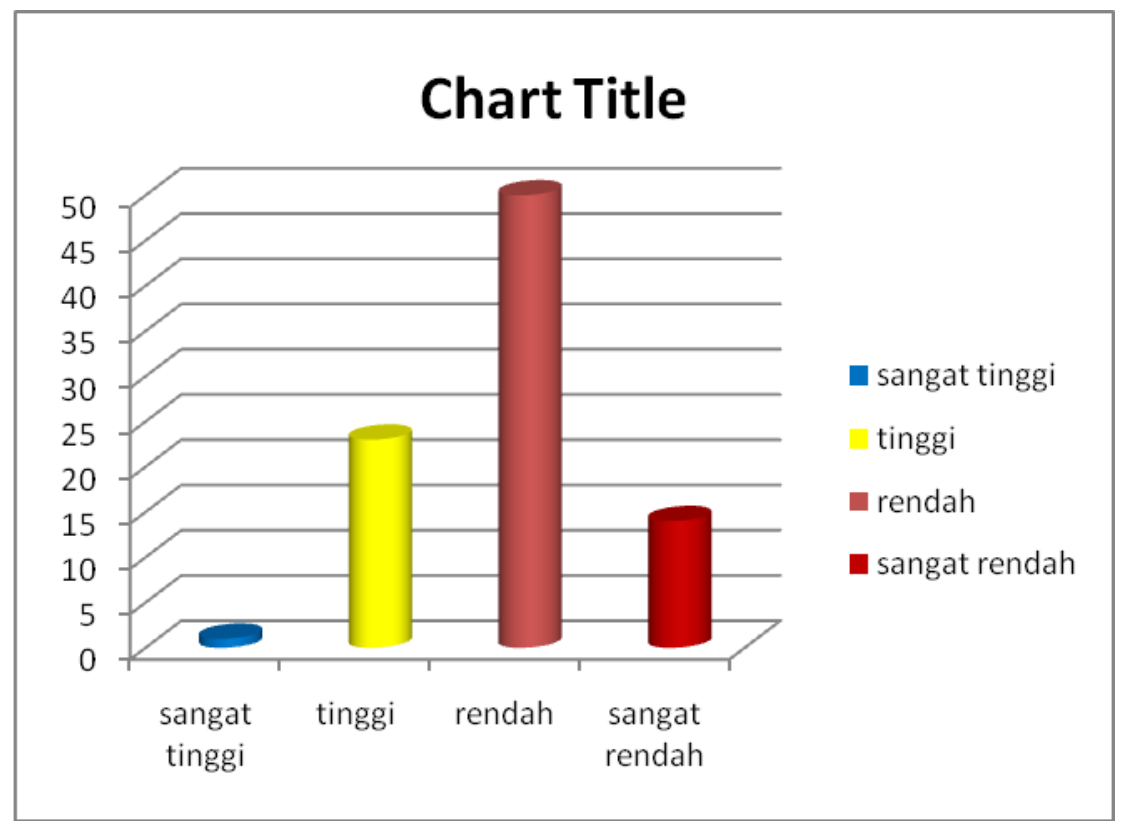

Gambar 03 Diagram kedisiplinan belajar

Dapat dilihat bahwa secara keselurahan variabel kedisiplinan belajar siswa sebagian besar masuk dalam kategori rendah dengan hasil frekuensi 50. Kategori ini bisa diartikan sebagai kategori siswa memiliki kedisiplinan belajar siswa kelas VIII SMP N 1 Kandangserang Pekalongan dinyatakan yang rendah. 


\section{Motivasi Belajar Siswa Kelas VIII SMP N 1 Kandangserang Pekalongan}

Variabel motivasi belajar memiliki nilai modus sebesar 61, berarti bahwa nilai kelompok motivasi belajar yang dimiliki oleh 88 siswa berada pada angka 61. Untuk nilai median sebesar 62.00 , yang berarti nilai tengah dari 88 siswa terletak 62.00,sementara untuk nilai mean yang dimiliki oleh 88 siswa sebesar 62.74 termasuk kategori rendah. Skala yang digunakan berisi tentang pernyataan mengenai motivasi belajar yang digunakan untuk mengetahui motivasi belajar siswa kelas VIII. Sebanyak 34 pernyataan yang diberikan dalam bentuk skala ini, siswa dapat memilih pendapat yang paling sesuai dengan keeadaan dirinya. Hasil analisis pengisian skala tersebut dikategorikan dalam empat tingkat yaitu sangat tinggi, tinggi, rendah, sangat rendah.

Tabel 05 Kategori interval motivasi belajar

\begin{tabular}{cccc}
\hline Kelas Interval & Frekuensi & Persentase & Kategori \\
\hline $81-90$ & 2 & $2,15 \%$ & Sangat Tinggi \\
$71-80$ & 26 & $28,10 \%$ & Tinggi \\
$62-70$ & 44 & $47,55 \%$ & Rendah \\
$53-61$ & 16 & $17,20 \%$ & Sangat Rendah \\
\hline Jumlah & $\mathbf{8 8}$ & $\mathbf{1 0 0 \%}$ & \\
\hline
\end{tabular}

Diperoleh hasil dari 88 siswa yang menjadi responden dalam penelitian ini, subjek dengan kategori motivasi belajar sangat tinggi sebanyak 2,15\%, siswa dengan kategori tinggi sebanyak $28,10 \%$, siswa dengan kategori rendah sebanyak $47,55 \%$, siswa dengan kategori sangat rendah sebanyak $17,20 \%$. Dengan demikian dilihat dari reratanya maupun dari mayoritasnya, dapat dinyatakan bahwa tingkat motivasi belajar siswa di SMP N 1 Kandangserang Pekalongan termasuk dalam kategori rendah.

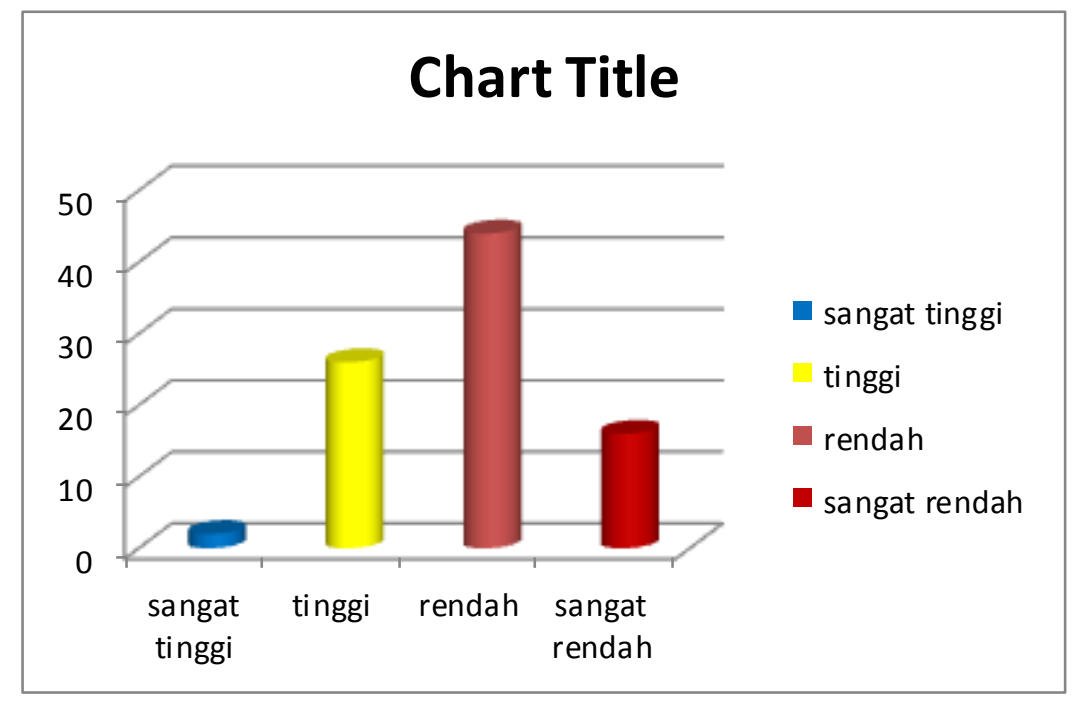

Gambar 04 Diagram batang motivasi belajar

Dapat dilihat bahwa secera keseluruhan variabel motivasi belajar siswa sebagian besar masuk dalam kategori rendah dengan hasil frekuensi 47. Kategori ini bisa diartikan sebagai kategori siswa memiliki motivasi belajar siswa kelas VIII SMP N 1 Kandangserang Pekalongan dalam kategorirendah, 
Terdapat hubungan yang positif dan signifikan antara kedisiplinan belajar dan cara belajar. Dibuktikan bahwa $t$ hitung $>t$ tabel atau 4,572>1,9874,572 $>1,987$ dengan nilai Sig. Sig. yang dihasilkan sebesar 0,000. Hal ini menunjukkan bahwa nilai Sig. $<\alpha^{S i g .}<\alpha$ atau 0,000 $<0,05^{0,000<0,05}$, sehingga dapat ditarik kesimpulan terdapat hubungan yang signifikan antara kedisiplinan belajar dengan cara belajar siswa kelas VIII SMP $\mathrm{N} 1$ Kandangserang Pekalongan.

Terdapat hubungan yang positif antara motivasi belajar dan cara belajar. Hal ini dibuktikan dengan nilai t hitung untuk variabel motivasi belajar sebesar 6,306 dan t tabel sebesar 1,987. $\mathrm{Hal}$ ini menunjukkan bahwa $\mathrm{t}$ hitung $>\mathrm{t}$ tabel atau 6,306>1,9876,306 $>1,987$ dengan nilai Sig. Sig. yang dihasilkan sebesar 0,000. Hal ini menunjukkan bahwa nilai Sig. $<\alpha$ Sig. $<\alpha$ atau $0,000<0,05^{0,000}<0,05$, sehingga dapat ditarik kesimpulan terdapat hubungan yang signifikan antara motivasi belajar dengan cara belajar siswa kelas VIII SMP N 1 Kandangserang Pekalongan

Terdapat hubungan yang positif antara kedisiplinan belajar dan motivasi belajar dengan cara belajar siswa kelas VIII SMP N 1 Kandangserang Pekalongan. Berdasarkan penelitian menggunakan skala psikologis yang peneliti gunakan, menunjukkan bahwa terdapat hubungan antara kedisiplinan belajar dan motivasi belajar dengan cara belajar. Hal ini dibuktikan dengan nilai signifikan bahwa $F$ hitung $>F$ tabel atau 21,152>1,987 $21,152>1,987$ dengan nilai Sig. Sig. yang dihasilkan sebesar 0,000. Hal ini menunjukkan bahwa nilai Sig. $<\alpha$ Sig. $<\alpha$ atau $0,000<0,05^{0,000<0,05}$. Dapat disimpulkan bahwa dengan adanya kedisiplinan belajar tinggi maka akan mempberikan dampak yang positif terhadap motivasi belajar yang dimiliki siswa.

\section{Simpulan dan Saran}

Terdapat hubungan yang positif antara kedisiplinan belajar dan motivasi belajar dengan cara belajar siswa kelas VIII SMP N 1 Kandangserang Pekalongan. Berdasarkan penelitian menggunakan skala psikologis yang peneliti gunakan, menunjukkan bahwa terdapat hubungan antara kedisiplinan belajar dan motivasi belajar dengan cara belajar. Hal ini dibuktikan dengan nilai signifikan bahwa $\mathrm{F}$ hitung $>\mathrm{F}$ tabel atau 21,152>1,98721,152>1,987 dengan nilai Sig. Sig. yang dihasilkan sebesar 0,000. Hal ini menunjukkan bahwa nilai Sig. $<\alpha$ Sig. $<\alpha$ atau $0,000<0,05^{0,000<0,05}$. Dapat disimpulkan bahwa dengan adanya kedisiplinan belajar tinggi maka akan mempberikan dampak yang positif terhadap motivasi belajar yang dimiliki siswa. Selain itu dengan adanya cara belajar siswa yang baik maka akan berpengaruh dengan hasil belajar siswa. Dengan seringnya siswa tersebut mempunyai kedisiplinan belajar yang tinggi , dan motivasi belajar yang tinggi, maka akan menambah cara belajar seperti halnya cara belajar siswa. Jadi semakin tinggi kedisiplinan belajar dan motivasi belajar maka akan semakin tinggi pula cara belajarnya. Sebaliknya semakin rendah tingkat kedisiplinan belajar dan motivasi belajar maka semakin rendsh pula tingkat cara belajar yang dimiliki siswa.

Berdasarkan simpulan diatas, maka peneliti memberi saran sebagai berikut: 1) Bagi siswa kedepannya harus dapat mempunyai kedisiplinan belajar yang baik dan motivasi yang tinggi dan juga harus mempunyai cara belajar yang baik agar dapat bertanggung jawab dalam belajar dan dirinya. 2) Guru BK hendaknya memberikan layanan bimbingan konseling sesuai dengan kebutuhan siswa. Siswa yang mempunyai masalah dalam kategori tinggi hendaknya diberikan konseling individu atau konseling kelompok. Siswa yang mempunyai maslah dalam kategori sedang hendaknya diberikan layanan bimbingan kelompok, selamjutnya jika siswa mempunyai masalah dalam kategori rendah maka diberikan layanan informasi

\section{Daftar Pustaka}

Amirudin. 2019. Penerapan Pendekatan VCT ( Value Clarification Teaching) Untuk Meningkatkan Kedisiplinan dan Hasil Belajar IPS Pada Siswa Kelas V SDN Telaga WaruKec. Praya, Kab. Lombok Tengah. Jurnal Ilmiah Mandala Education. Vol:5 No.1 
Arikunto, Suharsini. 2010. Prosedur Penilaian Suatu Pendekatan Praktik. Jakarta: PT Rineka Cipta

Dwi, Hera. 2017. Pengaruh Cara Belajar dan Disiplin Belajar Terhadap Hasil Belajar Mata Pelajaran Mengelola Peralatan Kantor Kelas X Administrasi Perkantoran SMK Batik 1 Surakarta. Vol: 1 No.1

Meriyanti. 2018. Hubungan Cara Belajar dengan Minat Belajar Siswa Kelas VIII MTs AshShohibiyah Bangun Purba Kabupaten Rokan Hulu Provinsi Riau. Instructional Development Journal. Vol:1 No.2

Puspita, Bella . 2017. Meningkatkan Kedisiplinan Belajar Siswa Melalui Manajemen Kelas. Vol:2 No.2

Rahmayanti, Vina. 2010. Pengaruh Minat Belajar Siswa dan Persepsi atas Upaya Guru dalam Memotivasi Belajar Siswa Terhadap Prestasi Belajar Bahasa Indonesia Siswa SMP di Depok. Vol:1 No.2

Sari, Indah. 2018. Motivasi Belajar Mahasiswa Program Studi Manajemen Dalam Penguasaan Ketrampilan Berbicara Bahasa Inggris. Jurnal Manajemen Tools. Vol:9 No.1

Sukardi, Jusuf. 2012. Pengantar Metodologi Penelitian. Jakarta: Mitra Wacana Media

Wahab, Rohmalina. 2015. Psikoogi Belajar.Jakarta: PT Raja Grafindo Persada

Wandi, Hamzan. 2016. Hubungan Kedisiplinan Belajar Siswa Dengan Cara Belajar Pada Mata Pelajaran Teknik Landasan Dasar di SMK Muhammadiyah 1 Padang. Vol:2 No.1

Yuliyantika, Siska. 2017. Analisis Faktor-faktor yang Memepengaruhi Disiplin Belajar Siswa KelasX,XI dan XII di SMA Bhakti Yasa Singaraja. Vol:9 No.1 